A - 11-15: 10

$$
\text { インプラント周囲溝渗出液における骨代謝マーカーの解析 }
$$

新潟大学歯学部歯科保存学第二講座、明海大学歯学部 ${ }^{*}$ 歯周病学講座、 ${ }^{*}$ 歯科臨床研究所

○村田雅史、辰巳順一 ${ }^{*}$ 、加藤裕未、須田 聡、布川寧子、小林之直 ${ }^{*}$ 、

武田宏幸*、荒木久生 ${ }^{* *}$ 、申 基喆*、宮田 隆*、奥田一博、吉江弘正

Analysis of Bone Metabolism Markers in Peri-implant Crevicular Fluid

Department of Periodontology, Niigata University Faculty of Dentistry, ${ }^{*}$ Department of Periodontology and ${ }^{* *}$ Post-doctoral Institute of Clinical Dentistry, Meikai University School of Dentistry

OMasashi Murata, Jun-ichi Tatsumi*, Yumi Kato, Satoru Suda, Yasuko Nunokawa, Yukinao Kobayashi *, Hiroyuki Takeda ${ }^{*}$, Hisao Araki ${ }^{*}$, , Kitetsu Shin ${ }^{*}$, Takashi Miyata ${ }^{*}$, Kazuhiro Okuda and Hiromasa Yoshie

キーワード : インプラント周囲溝沴出液、骨代謝マーカー、インプラント周囲炎

\title{
【目的】
}

インプラント植立後の周囲組織は、インプラント体と骨が直接結合しており、天然歯と異なり歯根膜や接合 上皮のような構造を持たない。そのためインプラントは細菌性プラークなどの侵襲に対る防御機構が脆弱であり、 インプラント周囲炎では急激な周囲骨の吸収が起こり、インプラント体の動摇をきたすことが知られている。イ ンプラント周囲溝㴉出液(PICF) はこのような侵襲に対する生体側の防御機構として重要な役割を果たしている と考えられる。演者らはこれまで、インプラント周囲炎患者のPICF中のTIMP-1/MMP-1+MMP-8比が歯周炎患者 のGCF 中のそれよりも有意に低く、インプラントでは天然歯に比較してTIMPによる周囲組織破壊に対する防御 反応が低下していることを報告した（Nomura T, et al. Clin Oral Implant Res. 2000 in press）。今回われわれは PICF中のDeoxypyridinoline (Dpd), Gla-type Osteocalcin (Gla-OC)を解析することで、急激な骨吸収が起こる以前に インプラント周囲骨組織の破壊を予測できないかその可能性について㭘討した。

【材料および方法】

1) 被験者は明海大学歯学部付属明海大学病院、PDI埼玉歯科診療所および新潟大学歯学部附属病院の 3 施設に おいてインプラントを植立されメインテナンスされている全身疾患を有しない患者のうち、インフォームドコン

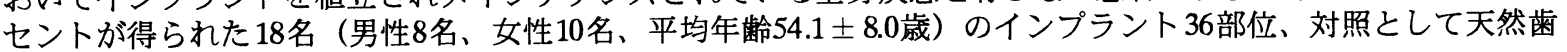
18部位を対象とした。

2) 臨床パラメーター (Plaque Index、Gingival Index、Probing Depth、Mobility; PERIOTEST、X線写真上の骨吸 収の有無）から Healthy Implant (Bone loss: -, GI: 0, PII $\leqq 1$ )、Peri-implant mucositis (Bone loss: -, GI: $\geqq 1$, PII $\geqq 1$ )、 Peri-implantitis (Bone loss: +, GI: $\geqq 1$, PII $\geqq 1$ )の3群に分類し、PICF、GCF、血清のサンプリングを行った。

3) PICFおよびGCFのサンプリングはペーパーストリップス法にて行った。すなわち 1 部位につきペーパース トリップス/60秒 x 10 回行い、単位時間あたりの量を採取してPERIOTRON $6000 に て$ 液量を測定した。その後抽 出Bufferに溶出し、遠心後に上清を回収して測定までー $80^{\circ} \mathrm{C} に て$ 保存した。

4) PICF、GCFおよび血清中のDpd、Gla-OC、IL-1 $\beta$ 蛋白量の測定にはそれぞれ市販のELISA kit を使用した。

5) 各群間におけるマーカーの比較には分散分析（ANOVA）および多重比較検定として Schefféの方法を用いた。

【結果と考察】

1) 臨床パラメーターから診断した結果、被験インプラント各群の内訳はHealthy Implant群 : 22、Peri-implant mucositis群 : 8、Peri-implantitis 群 : 6であった。

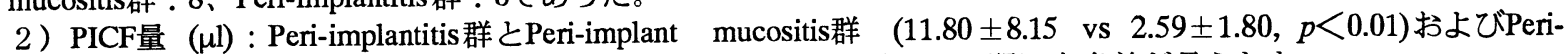
implantitis群とHealthy Implant群 (11.80 \pm 8.15 vs $1.28 \pm 1.43, p<0.01)$ の間に有意差が見られた。

3 ) $\operatorname{Dpd}(\mathrm{nM} / \mathrm{L})$ : いずれの群間にも有意差は認められなかった $(p>0.05)$ 。

4) Gla-OC $(\mathrm{ng} / \mathrm{ml})$ : Peri-implant mucositis群とHealthy Implant群の間に有意差が見られた $(0.67 \pm 0.18$ vs $0.30 \pm$ $0.29, p<0.01)$.が、他の群間では有意差は見られなかった $(p>0.05)$ 。

5 ) IL-1 $\beta(\mathrm{pg} / \mathrm{ml})$ : Peri-implantitis群とPeri-implant mucositis群 (321.00 \pm 440.24 vs $29.85 \pm 38.66, p<0.05)$ および Peri-implantitis群とHealthy Implant群 $(321.00 \pm 440.24 \mathrm{vs} 23.95 \pm 22.99, p<0.01)$ の間に有意差が見られた。

Gla-OCがPeri-implant mucositis群で有意に高い值を示し、有意差は認められなかったがDpdも同様にPeriimplant mucositis群で高い傾向が見られたことから、mucositisの時点でインプラント周囲骨の吸収が起こる前段 階としてインプラント周囲骨の代謝が高まり、吸収系に推移していく可能性が示唆された。以上の結果から、 PICF中の骨代謝マ一カーが、インプラント周囲骨組織の状態を反映している可能性が示唆された。 
日本人歯周炎患者におけるIL-1遺伝子多型性の解析 大阪大学大学院歯学研究科口腔分子免疫制御学講座

○平野裕之、村上伸也、北村正博、佐保輝之、野崎剛徳、高山真一、小郷秀司、 寺倉まみ、松尾理絵、竹内圭子、神山章、酒井洋子、岡田 宏

IL-1 genotype analysis in Japanese periodontitis patients

Osaka university graduate school of dentistry Division of oral biology and disease control

OHiroyuki Hirano,Shinya Murakami, Masahiro Kitamura, Tenuyuki Saho, Takenori Nozaki,

Shinichi Takayama, Hideji Ogo, Mami Terakura, Rie Matsuo, Keiko Takeuchi, Akira

Kouyama, Youko Sakai,Hiroshi Okada

キーワード IL-1 遺伝子多型性、成人性歯周炎

【目的】炎症性サイトカインのうちIL-1 $\alpha 、$ IL-1ßの遺伝子多型性が白人アメリカ人における成人性 歯周炎の重篤度に影響を及ぼす危険因子のひとつであることが報告されている。そこで本研究では、 日本人の成人性歯周炎患者を対象としてIL-1 $\alpha 、$ IL-1 $\beta$ 発現調節領域遺伝子（IL-1A、IL-1B）の遺伝子 型 (polymorphism) を解析し、健常な歯周組織を有する検体と比較することでIL-1遺伝子多型性が日 本人の歯周病の重篤度、罹患性に影響を及ぼすか否かを検討した。

【材料及び方法】

1) 対象: 大阪大学歯学部倫理委員会の承認のもと、本研究への参加の応諾が得られた者を対象に中 等度以上の成人性歯周炎と判定された非喫煙患者 51 名、軽度歯周炎患者 48 名（35 歳以上55歳 未満）およびボランティア 64 名から末梢血約 $0.5 \mathrm{ml}$ を採取した。同検体を材料として IL-1遺伝子多 型性を判定した。2）成人性歯周炎重篤度は、残存歯が12 歯以上存在し、デンタルレントゲン撮影 により、残存歯の平均骨欠損（エナメルセメント境から歯槽骨縁までの距離）が $3 \mathrm{~mm}$ 以上、あるい は $3 \mathrm{~mm}$ 以上の骨欠損を有する歯牙が 10 歯以上存在し、かつ各 $1 / 4$ 顎に当該歯牙がそれぞれ 2 歯以 上存在する患者を中等度以上の成人性歯周病患者とした。また、2 4 歯以上の歯牙を有する 35 歳以 上. 65 歳以下のボランティアのうち、3 mm以上の骨欠損が全顎で 2 部位以下の被験者を健常者に分 類した。上記分類の中間に位置する被験者を軽度歯周炎患者とした。3) IL-1遺伝子多型性の解析：

採血した末梢血から鋳型DNAを抽出し、PCRを行った。IL-1Aは+4845の位置、IL-1Bは+39530)位置を 含むゲノムDNA領域をPCRにて増幅し、得られたDNAをそれぞれFnu4 HIとTaqlにて処理後、電気泳動 し泳動パターンにより遺伝子型を判定した。IL-1A（+4845）、IL-1B (+3953) ともにアリル20遺伝 子型を少なくとも 1 コピー有する被験者をIL-1遺伝子型陽性と判定した。

【結果】

1) 本実験に参加した被験者は中等度以上の成人性歯周炎患者 51 名、軽度成人性歯周炎患者 48 名、健常者 19 名に分類された。2) 今回実験に参加した全日本人のIL-1遺伝子多型性を解析したと ころ、1 63 名中 12 名がIL-1陽性で、陽性率は7.36\%であった。2) IL-1陽性を示した被験者は、成 人性歯周炎患者 51 名中に 2 名（陽性率3.9\%）、軽度成人性歯周炎患者 48 名中に 4 名（陽性率 8.3\%）検出されたものの、健常者 19 名には検出されなかった（陽性率0\%）。3） IL-1 $\alpha$ ならびに IL-1 3 遺伝子のアリル 2 保有率：アリル 2 保有によりもたらされるIL-1高産生性は、アリル 2 をホモ あるいはへテロに有するか否かにより影響を受ける可能性がある。そこで日本人被験者におけるIL-1 $\alpha$ ならびにIL-1 $\beta$ アリル 2 のホモハテロ保有率を検討したところ、アリル2をホモに有卞る被験者は 両locusとも成人性歯周炎患者を含めて全被験者において皆無であった。

【考察】

今四実験に参㞦した日本人被験者 163 名中のIL-1遺伝子型陽性率 7.36\%は、アジア系民族のうち、 中国人を対象にした解析結果（３％）を越えるものではあったものの、コーカサス人種の陽性率（3 $0 \%$ ）をはるかに下回る低い数值であり、IL-1遺伝子型陽性率に人種間で差異があきらかに存在する ことが示された。また、日本人歯周炎患者においてIL-1遺伝子型陽性率が必ずしも高くないことが現 時点での中間報告として示された。IL-1 以外のサイトカインに関しても遺伝子多型性が存在すること が明らかにされており、今後の興味深い研究対象となるものと期待される。これらのことを念頭に於 き、令後さらに症例数を増加させることが歯周炎重篤度とIL-1遺伝子多型性との関連を結論づけるた めには必要と思われる。

【結論】

被験者を歯周病の病状により分類した結果、日本人では成人性歯周炎患者において $\mathrm{L}-1$ 陽性率は3.9\% と必ずしも高くないことが現時点の実験結果から示され、日本人の歯周炎に対する易感受性がIL-1遺 伝子多型性のみでは説明されないことが強く示唆された。 
A $-13-15: 30$

日本人早期発症型歯周炎患者における TNF- $\alpha$ 遺伝子多型の解析 新潟大学歯学部歯科保存学第二講座

○遠滕基広、田井秀明、多部田康一、小林哲夫、山崎和久、吉江弘正 Analysis of genetic polymomhisms in the 5'-flanking region of tumor necrosis factor alpha gene in Japanese patients with early-onset periodontitis Department of Periodontology, Faculty of Dentistry, Niigata University

OMotohiro Endo, Hideaki Tai, Kouichi Tabeta, Tetsuo Kobayashi, Kazuhisa Yamazaki, Hiromasa Yoshie

キーワード : 早期発症型歯周炎、TNF- $\alpha$ 、遺伝子多型

【目的】

歯周病は多様な要因により引き起こされる炎症性疾患であり、その一つに宿主側の要因があげられる。最近、宿主因 子として遺伝子多型が疾患の発症やその重症度に関与しているとの報告が自己免疫疾患や歯周疾患においてなされて いる。以前より炎症性サイトカインである TNF$\alpha$ 産生量および転写活性との関連性も示悛されている。また、これら遺伝子多型の頻度は人種によって異なることが 報告されている。

そこで本研究では日本人健常者における TNF- 遺伝子多型の頻度をシークエンス解析及び PCR-SSOP(sequence specific oligonucleotide probe)法を用いて桧索し、さらに早期発症型歯周炎 (EOP) 患者と TNF- $\alpha$ 遺伝子多型の関連性について 検矿を行つた。

【材料と方法】

同意を得た EOP 患者4 7名、健常者 (HS) 105 名を対象とし歯周組織娭査及び採血を行つた。採取した末梢血から ゲノム DNA を抽出し、まず健常者 20 名について TNF- $\alpha$ 5側の-1220 から+154 までの範囲を PCR 堌幅後、サブクロ 一ニングしオートシークエンサーにて多型のスクリーニング及びハプロタイプを決定した。次に、全被験者について 5 力所の多型 (-1031/-863/-857/-308/-238) を PCR-SSOP 法を用いて梌索し遺伝子、アレル、ハプロタイプ頻度および各被 験者ごとのハプロタイプの組み合わせを決定した。それぞれの結果について統棓処理を行い、䀦床パラメーターとの 関連性について解析を行つた。

【結果]

1）日本人では遺伝子多型が 5 カ所で認められ、6種類のハプロタイプ、11パターンのハプロタイプの組み合わせ を決定した。

2）どちらのハプロタイプにも多型がない群を H1/H1、片方のみ-857 に多型がある群を $\mathrm{H} 1 / \mathrm{H} 3$ とすると、 $\mathrm{H} 1 / \mathrm{H} 3$ 群の 頻度はEOP(12.8\%)においてHS(27.6\%)に比へ有意に低い值を示した $(p=0.04)$ 。

3） EOP 患者において $\mathrm{H} 1 / \mathrm{H} 3$ 群が $\mathrm{H} 1 / \mathrm{H} 1$ 群と比べ付着の妻失(PAL)が $6 \mathrm{~mm}$ 以上の部位が占める割合が有意に少なか つた( $\mathrm{p}=0.04)$ 。

4） EOP 患者において PAL $6 \mathrm{~mm}$ 以上の部位が 5\%未満と 5\%以上、又は $10 \%$ 未満と $10 \%$ 以上に分け $\mathrm{H} 1 / \mathrm{H} 3$ 群の頻度 を比較すると、ともに $5 \%$ 以上 $10 \%$ 以上で有意に頻度が少なかった(5\%: $p=0.04,10 \%: p=0.01)$ 。

【考察および結論】

以上の結果より、TNF- $\alpha$ 遺伝子多型のうち $\mathrm{H} 1 / \mathrm{H} 3$ 群 は、早期発症型歯周炎における歯周組織の破壊には抑制的に作 用し、また、歯周疾患の遺伝的マーカーとしての可能性が示悛された。 


\section{歯周痴患における老化の関わり 一歯周病患者の末梢血白血球のテロメア長一}

明海大学 歯学部 歯周病学講座

○西田栄昭, 高橋慶壮, 武田宏幸, 深沢宗主, 東 高史, 本平一志, 熊谷敬史, 辰巳順一, 宮田 隆

Association of aging on periodontal disease

- Telomere length of peripheral blood leukocytes in the patients with periodontitis -

Department of Periodontology, Meikai University School of Dentistry

OHideaki Nishida, Keiso Takahashi, Hiroyuki Takeda, Munemoto Fukazawa, Takashi Azuma, Hitoshi Motohira,

Takashi Kumagai, Junichi Tatsumi and Takashi Miyata

キーワード:歯周疾患, 老化, テロメア長

\section{【目的】}

老化は歯周疾患のリスク因子と考えられている。ダウン症およびインスリン依存性糖尿病患者は,「早期老化症」 と呼ばれており，歯周病に易罹患性を示す。このことは，老化が歯周病のリスク因子である事を支持するものの， その機序は明らかでない。これらの患者由来末梢血白血球のテロメア長および培養線維芽細胞のテロメア長の短縮 率が同年代の健常者のそれらに比較して短いことがわかっている。テロメアは染色体末端に位置し, その長さは細 胞老化の指標とされている。したがって、ある種の歯周疾患はテロメア長の短縮率から説明できるかもしれない。 しかし, 歯周病における老化のかかわりをテロメア長およびその短縮率から調べた研究は無い。本研究では歯周病 病態における老化のかかわりを評価するための最初のステップとして, 早期発症型歯周炎患者の末梢血白血球のテ ロメア長を調べた。

\section{【材料および方法】}

1. 被験者:明海大学歯学部付属病院歯周病科に来院した早期発症型歯周炎患者4名および同年齢の健常者 16 名か ら末梢血を採取した。

2. ゲノムDNAの抽出：DNA Extractor WB Kit（Wako）を用いて末梢血からゲノム DNA を抽出した。

3. テロメア長の検出:抽出した DNA を制限酵素（Hinf I /Rsa I ）で消化し，0.6\%アガロースゲル電気泳動で分離 した後ナイロンメンブレンに転写し，(TTAGGG） 4 をジゴキシゲニンでラベルしたものをプローブとして用 いたサザンハイブリダイゼーションを行い, テロメア長を調べた。

\section{【結果】}

1. DNA10 0 g から9Kbpから $5 \mathrm{Kbp}$ のテロメア長を特異的に検出できた。2Kbp 以下の部位に非特異的な反応が見られた。

2. 健常者と比較して, 調べた早期発症型歯周炎患者の末梢血白血球のテロメア長に, 有意な短縮は認められなかった。

\section{【考察および結論】}

本研究で調べた早期発症型歯周炎患者の末梢血白血球に明らかなテロメア長の短縮は見られなかった。今後, 被 験者数を増やし，末梢血白血球のテロメア長および歯周組織構築細胞（歯肉線維芽細胞, 歯根膜線維芽細胞）の継 代ごとのテロメア長の短縮率を調べていく予定である。また, 本結果はテロメア長の平均値を比較しているにすぎ ず，染色体ごとのテロメア長を調べる必要があるかもしれない。 


\section{初期の実験的歯周病罹患歯の微小荷重に対する変位動態 九州歯科大学歯科保存学第二講座}

○元島ふくみ、田隅志保、内藤 徹、日高理智、横田 誠

The Measurement of Tooth Displacement under Small Loading on Experimental Periodontitis in onset phase

Department of Periodontology and Endodontology, Kyushu Dental College

Fukumi Motoshima, Shiho Tazumi, Toru Naito, Masatoshi Hitaka and Makoto Yokota

キーワード : Experimental periodontitis, tooth displacement, tooth mobility

【目的】本教室では従来、病的な歯の機能的動態についての研究を行ってきた。秋吉は、微小荷 重に対する歯の垂直変位は実験的歯周炎惹起後 1 週目で大きく増加し、その後は 3 週目まで緩やか な増加を示すことを明らかにした。しかし、顕著な変化を生じた 1 週間以内における詳細な観察は なされていない。今回我々は、機能的変化がどの時点で発生するか、またその変化がどのような臨 床パラメータと相関するかを検討するため、実験的歯周炎惹起後 $1 、 3 、 6$ 日目の垂直変位を観察し た。

【材料と方法】健康な体重 $8 \sim 10 \mathrm{~kg}$ のビーグル成犬 6 頭を用いた。被験歯は下顎左側第三前且歯

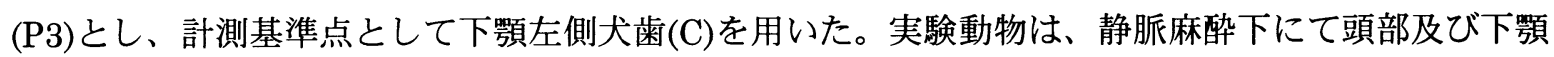
部を測定台に固定し、変位測定は、分解能 $1 \mu \mathrm{m}$ の高精度レーザー变位計を用いて行った。歯に対 して荷重は、垂直的に $10 \mathrm{~g}$ から $100 \mathrm{~g}$ まで $10 \mathrm{~g}$ 刻みに 2 回ずつ加えられ、その変位量の平均值を算 出した。計測間隔は 0.01 秒、負荷時間は 30 秒とし、回復時間は 5 分に設定することで前荷重の影 響が残存しないよう配虑した。呼吸、脈拍、体動などの影響を考慮し、P3 と C の変位の差分を算 出し、可及的にノイズを排除した。変位測定はベースラインとデンタルフロス結紮による歯周炎惹 起後 1 日目、3 日目、6 日目に行い、歯周病学的臨床パラメータ（PPD·PAL、ペリオトロン值、ペ リオテスト值、X-ray）も同時に採取した。得られたデータは $\mathrm{AD}$ 変換後、パーソナルコンピュータ 一にて分析を行った。

【結果および考察】1. 歯の沈下距離の変化は、実験的歯周炎惹起後 $1 、 3$ 日目と比較し 6 日目で 有意な増大を示した。

2.1 週間以内の初期の実験的歯周炎に関しても、前回同様、 負荷直後の速い沈下とその後のゆっくりとした沈下の 2 相 の変位様式が観察された。

3. 沈下距離と歯周病学的臨床パラメータとの回帰分析により、 沈下距離はPPD、ペリオトロン値と有意な相関を示した。

4. すべての歯周病学的臨床パラメー夕において、1、3 日目に 比較し 6 日目で著明な変化が認められたが、同時期に機能 的変化としての歯の沈下距離の増加も認められた。

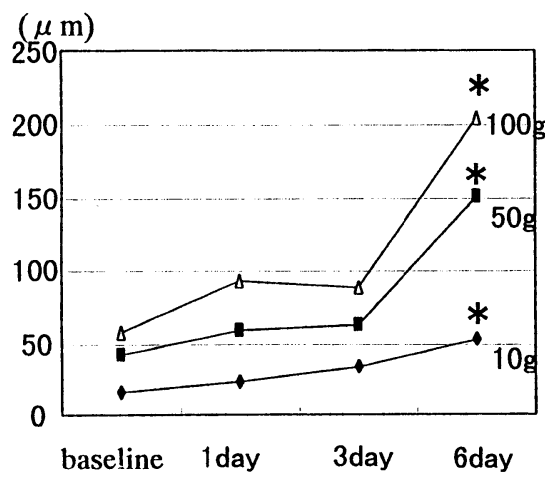

沈下距離の変化(10g,50g,100g負荷時) 
A $-16-16: 00$

薬剤の変更の有無による歯周組織の反応性について

九州歯科大学歯科保存学第 2 講座

○村岡 宏祐、安蘓 恭子、高橋 美帆、田代 芳之、久保田 浩三、横田 誠

Existence of change on Nifedipine-induced gingival overgrowth according to response of periodontium

Department of Periodontology and Endodontology, Kyushu Dental College

OKosuke Muraoka, Kyoko Aso, Miho Takahashi, Yoshiyuki Tashiro, Kohzoh Kubota and Makoto Yokota

キーワード : ニフェジピン性歯肉增殖症, 基本治療, ポケットの減少

【目的】

ニフェジピン性歯肉增殖症の治療は、従来、薬剤の変更・中止などが選択されている。しかしな がら、薬剤の変更の有効性の根拠については明確にされていない。前回我々は、ニフェジピン性歯 肉増殖症に対し、基本治療のみで改善した症例を発表した。そこで今回は、ニフェジピンを服用し、 歯肉増殖を有する患者で、薬剤の変更した場合（変更群）と変更しなかった場合（非変更群）の基 本治療に対する歯周組織の反応の違いについて比較検討することである。

【材料と方法】

研究対象者は、九州歯科大学付属病院を受診し、高血圧症のみに既往歷があり、ニフェジピン性 歯肉增殖を伴う歯周炎と診断した 10 名のうち、薬剤の変更群、 4 名、平均年齢 $58.3 \pm 7.41$ 歳、薬 剂の非変更群、6 名、平均年齢 $68.5 \pm 11.47$ 歳である。初診時と再評価時に採取した臨床パラメー ターは、PPD、PAL、BOP、排膿であった。基本治療中、プラークコントロールレコードは、 $20 \%$ 以下になるように指導した。

統計処理は、変更群と非変更群における臨床パラメーターの初診時、再評価時、初診時から再評 価時の差を $t$-test にて行った。また、変更群と非変更群の各々の初診時の各ポケット群における比 較をPPD、PALに関して、two-way ANOVA、Mann-Whitney's U test を用いて行った。

【結果および考察】

年齢、治療期間の間には有意な相関は認められず、これらの因子がニフェジピン性歯肉増殖症の 治癒に与える影響は少ないと考えられた。変更群、非変更群において顕著な組織反応が見られた。

初診時、再評価時、初診時から再評価時の差の臨床パラメーターにも、両者の間で有意差を認め なかった。しかしながら、初診時と再評価時の PPD、PAL の関係は、浅い PPD において、変更群 と非変更群を比較して、非変更群の方で反応が悪いことが解った。

今回、ニフェジピン性歯肉増殖に罹患した患者の基本治療においては、薬物の変更を行わなくて も、歯周組織の改善に差は認められなかった。 
プラークコントロール下におけるインプラント周囲軟組織の血管再構築 神奈川歯科大学口腔解剖学教室、*愛知学院大学歯学部歯科理工学講座 ○岸 好彰、高橋好文*、東 分吉*、長谷川二郎*、高橋和人 Regeneration of peri-implant oral mucosal microvascular architecture under plaque control.

Department of Oral Anatomy, Kanagawa Dental College, *Department of Dental Materials Science, School of Dentistry, Aichi-Gakuin University.

OYoshiaki kishi, Yoshifumi Takahashi*, Bunkichi Azuma*, Jiro Hasegawa*, Kazuto Takahashi

キーワード : インプラント界面上皮下の血管再構築、血管鋳型法、走査電顕

【目的】歯科インプラントにおける防御機構としての、インプラント界面上皮下 に再生される血管網の評価を微小循環の側から検索する。天然歯ではエナメル質付 着上皮との接着、歯肉溝への浸出液による自浄作用、好中球游走による食食作用な どにより歯肉自身は防御され、ひいては歯槽骨への口腔内感染を阻止していると考 えられている。このうち浸出液や好中球は付着上皮下の微細血管網に由来してい る。今回はインプラント界面上皮下に、付着上皮下にみられた微細血管網に相当す る血管網が再構築されるか、微細血管鋳型法と走査電顕を用いて検索した。

【材料および方法】実験動物 : あらかじめ下頢臼歯部を抜歯し、3力月経過した 体重 $15 \mathrm{~kg}$ 前後の雄ビーグル犬4頭の下顎骨に、チタン・インプラント（ADS; All Dimple System Implants, 直径 $3.8 \mathrm{~mm}$ 、全長 $11.5 \mathrm{~mm}$ 、骨内埋入 $8 \mathrm{~mm}$ ）を植立した。 植立して3力月後から歯ブラシによるプラークコントロールを食後、毎日1回、42日 間行った。実験方法 : 一群は痳酔下で総頸動脈を剖出して潅流用チューブを挿入、

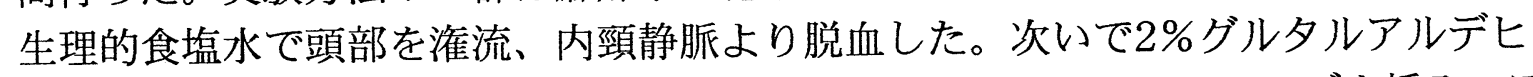
ドで潅流固定し、下顎骨を切除した。下歯槽動脈から注入用のチューブを扦入、ア クリル系合成樹脂（メルコックス、大日本インクK.K.）を注入した。酸・アルカリ 溶液で下顎骨を溶解して血管鋳型だけの標本とした。試料を切り出して試料台に固 定、白金パラジュウムをイオン蒸着して走査電顕で観察した。他群は組織切片と し、HE染色をほどこして光顕で観察した。

【結果・考察】インプラント植立のために切除された口腔上皮は、インプラント と接することによってインプラント表面に沿って増殖、オーバーハングしてあたか も付着上皮のように再生された。プラークコントロールされていた部位のインプラ ント界面上皮下には、同じくプラークコントロールされた正常な歯肉の付着上皮下 にみられた魚網あるいは亀甲状と同様の分布形態をした微細血管網が再生された。 
A $-18-9: 10$

走査電顕によるヒト歯セメント象牙境の構造について 北海道大学大学院歯学研究科 口腔健康科学講座

○山本恒之

The structure of the cemento-dentinal junction in human teeth shown by scanning electron microscopy

Department of Oral Health Sciences, Hokkaido University

Graduate School of Dentistry

OTsuneyuki Yamamoto

キーワード : セメント象牙境、ヒト歯、浸軟処理

「目的」

我々は、ヒト下顎大臼歯を用いてセメント象牙境の構造を光顕と電顕により研究してき た。その結果、セメント象牙境は幅が $2 \mu \mathrm{m}$ 程で、線維にそしく糖蛋白質に富むことを 明らかにした (Yamamoto et al. 1999, 2000)。本研究の目的は、「セメント象牙境は線維 に乏しい」という特徵は、他歯種においてもつねに存在するのかを確かめるために行わ れた。

「材料および方法」

$10 \%$ ホルマリン溶液にて本講座に保存してあったヒト上顎の中切歯、犬歯、第一小臼 歯のそれぞれ 20 本を材料とした。E D T Aによる脱灰後、材料をカミソリで近遠心方 向に半切しさらに凍結ミクロトームで切断面を滑沢にした。10\% N a OHに室温で 3 -4 日間、あるいはそれ以上浸漬した後、蒸留水に 1 日間水洗した。その際、一部試料 ではセメント質が象牙質から剥離した。全ての試料を通法に従い走査電顕用に処理した。 セメント質が剥がれていない試料ではセメント象牙境の縦断像を観察し、剥がれたセメ

ント質ではセメント象牙境を覆うセメント質内面を観察した。

「結果」

$\mathrm{N}$ a OH浸軟処理により線維以外の基質を除去した結果、セメント象牙境の立体線維構 築を観察することができた。無細胞セメント質では、セメント象牙境は幅が $2 \mu \mathrm{m}$ 程で線 維に乏しく、象牙質とセメント質の線維同士の絡み合いは部分的に認められるのみであ った。歯種による違い、同一歯での部位による違いは無かった。有細胞セメント質では、 全歯で、セメント質内面のシャーピー線維と固有線維の分布・配列は部位により異なっ ていた。しかしながら、「セメント象牙境は線維にそしい」という特徵については歯種と 部位による違いは無かった。

「考察」

本研究の結果は、下顎大臼歯でのセメント象牙境の組織学的特徵は、ほぼ全歯種に共通 することを示唆する。さらに、「セメント質と象牙質の接着には、線維同士の絡み合いよ りも介在する糖蛋白質がより深く関与する」という考えが全歯種にあてはまることもあ わせて示唆している。 
抜歯後の歯槽骨におけるプロテオグリカンの免疫組織化学的検討

朝日大学歯学部歯周病学講座

○牧 克教、啮谷俊昭、村井規悦、岩山幸雄

Immunohistochemical localization of proteoglycans in alveolarbone after tooth extraction in rat Department of Periodontology, Asahi university School of Dentistry

Katsunori Maki, Toshiaki Shibutani, Noriyoshi Murai, Yukio Iwayama

キーワード：歯槽骨、抜歯窩、プロテオグリカン

[目的]

プロテオグリカン（PG）は、細胞外マトリックスの主成分の一つであり、組織構造の維持、イオン平衡、 浸透圧の維持、物質の貯留などの重要な役割を果たしている。このPG は、コア蛋白質と呼ばれる部分と、 二䋖繰り返し構造を持つグリコサミノグリカン (GAG) が結合して構成される。歯肉組織の GAG には上 アルロン酸（HA）、コンドロイチン 4 硫酸（C4S）、コンドロイチン 6 硫酸（C6S）、デルマタン硫酸 (DS)、 ヘパラン硫酸（HS）の存在が報告されている。またこれら GAG は歯周炎の進展に伴い局在ならびに量的 レベルが変動することが知られている。しかし創傷治癒時の歯周組織中の PG や GAG の変化については 充分に解明されていない。そこで本研究は、ラットの田歯を実験的に抜去し、その治瘾過程における歯肉、 歯槽骨におけるデコリン、バーシカン、C4S、C6S、DS、HA の局在を免疫組織化学的に検討した。 [材料および方法］

実験動物には 13 週齢 Wister 系雄性ラット 16 匹を用いた。上顎第 1 日歯を顕微鏡下で抜去した、抜歯は屠 殺の 28 日、14 日、7 日、1 時間前に行い、以降の処理を同一条件で行った。4\%パラホルムアルデヒド溶 液で固定後、EDTA 溶液で脱灰し、通法に従いパラフィン包埋し薄切切片を作製した。抗体には抗デコリ ン抗体 (Chemicon International USA)、抗バーシカン抗体 (American Research Products USA)、抗L PG $\triangle$ Di-4S 抗体（2-B-6)、抗么 PG $\Delta$ Di-6S 抗体（3-B-3）、ビオチン標識ヒアルロン酸結合性タンパク（B-HABP）（生 化学工業）をそれぞれ用いた。二次抗体からはヒストファインキット（ニチレイ）を用いてビオチンース トレプトビジン法により免疫組織染色を行った。ペルオキシダーゼを発色させる基質として 3-3diaminobenzine tetrahydrochloride (DAB) を用い、ヘマトキシリンで核染色を行い、光学顕微鏡にて観察し た。なお 2-B-6 抗体、3-B-3 抗体にはそれぞれコンドロイチナーゼ ABC、コンドロイチナーゼ ACII 、コ ンドロイチナーゼ B (生化学工業) を切片上で反応後に染色を行った。また㐘槽骨代謝に対しては各種骨 代謝マーカーによる染色も併せておこなった。

[結果]

抜歯窩は初期には炎症性細胞の浸潤が見られ、徐々に歯肉、結合組織、歯槽骨の再生が観察された。抜歯 窝の治瘾に伴う結合組織線維の再生によりバーシカン、DS、C4S、C6S、HA では陽性部位と陽性強度の 增加が見られた。14日目には上皮の進展がみられ、それに伴い HA が細胞間隙に陽性像を示した。28 日 目には歯肉結合組織では結合組織線維の形成が著明となった。デコリンは正常時と比較し染色強度が減少 傾向であった。㐘槽骨の代謝に伴い破骨細胞や骨芽細胞が観察され、骨表面にテコリン、バーシカンなど の陽性反応がみられた。

[結論]

PG や GAG は実験的抜歯窩の治癒過程において局在性に変化が見られたことから、歯肉や歯槽骨を構成す る細胞の分化、増殖に関与し歯周組織修復に関連する可能性が示唆された。 


\title{
歯根形成における Smads の局在
}

\author{
日本大学歯学部保存学教室歯周病学講座, $*$ 解剖学教室第 2 講座 \\ ○佐藤慶伴, 江田昌弘, 吉沼直人, 伊藤公一, 稲毛稔彦* \\ Localizations of Smads during Root Formation
}

Departments of Periodontology and*Anatomy , Nihon University School of Dentistry

OMichitomo Sato, Masahiro Eda, Naoto Yoshinuma, Koichi Ito and Toshihiko Inage*

キーワード：歯根形成, Smad, BMP

【目 的】

エナメル質は外胚葉に由来するエナメル芽細胞と間葉に由来する象牙芽細胞との密接な相互作用（上皮一間葉 相互作用) によって形成される。歯根形成においてもへルトビッヒ上皮鞘 (HERS) が間葉細胞の誘導に関して 㐘根象牙質，セメント貿および歯根膜において重要な役割を果たしているものと考えられる。Bone morphogenetic protein (BMP) は異所性の骨誘導能を有するタンパクで, 骨芽細胞の初期分化や細胞外マ卜 リックスの合成を調節するなど多様な機能を持つことが報告されているが, 上皮一間葉相互作用のシグナル伝達 物質として歯根形成に関係していることが示唆されている。近年の研究で, Smads は BMP 含む transforming growth factor ( TGF ) - $\beta$ super family の細胞内シグナル伝達物質として TGF- $\beta$ super family の作用を制御す ることが報告されている。Smad 1,5,8 は BMP 特異型, Smad 2, 3 は TGF- $\beta$ 特異型, Smad 6, 7 は抑制型と して作用している。また, Smad 4 は共有型で特異型の Smad と結合して標的遺伝子を活性化する。

そこで, 演者らは歯根形成における BMP を含む TGF- $\beta$ super family の機能を検索する目的で, ラット曰四を 用いて Smads の局在を検討した。

【材料および方法】

1. 実験動物には生後 1〜6 週の Wistar 系雄性ラット 24 匹を用いた。 Nembutal ( $0.05 \mathrm{mg} / \mathrm{g}$ ) 麻酔下で, $4 \%$ パラフォルムアルデヒド溶液を用いて左心室から灌流固定を行った。固定後, 上下䫟臼歯部を取り出し, 同固 定液でさらに $4{ }^{\circ} \mathrm{C}$ で 4 時間浸漬固定を行った。試料は $0.1 \mathrm{M}$ EDTA 溶液にて脱灰後, アルコ一ルで脱水して矢 状断にて約 $5 \mu \mathrm{m}$ のパラフィン切片とした。

2. 免疫組織学的検索方法

1) 抗体：本研究では Smad 1, 4,6 抗体 (Santa Cruz Biotechnology, Inc.) を用いた。各抗体は他の Smads と交差反応を示さないことが免疫ブロッティング法で確認されている。

2) 免疫染色性 $\mathrm{ABC}$ 法で行い, 1\% methylgreen で核染色を行った。

\section{【結 果】}

歯冠部の外形が完成した時期では，内外エナメル上皮から構成される cervical loop は歯根を形成するため, HERS として下方にのび出している。HERS の㐘乳頭側には象牙質が形成され, HERS の先端部から歯冠側に向 かって米乳頭細胞, 前象牙芽細胞および分泌期象牙芽細胞が観察される。歯胚の下方中央部では根分岐部の形成 がはじまっており，その部に上皮隔膜が観察され，歯胚の周囲には将来歯槽骨となる骨組織の形成がみられる。 この時期では Smad 1, 6 抗体による免疫反応は HERS およびこれに面する歯乳頭細胞, 前象牙芽細胞, 分泌期初 期の象牙芽細胞および HERS 側方部の結合組織細胞にみられたが，弱い反応であった。

歯根象牙質の形成が進むと歯根表面にセメント留の形成が始まる。Smad 1, 6 抗体の免疫反応は歯根形成開始期 と同様に HERS，菌乳頭細胞，前象牙芽細胞，象牙芽細胞およびセメント芽細胞にみられ，槽間中隔および根間 中隔頂部の骨芽細胞においても強い免疫反応が観察された。

歯根がほぼ完成された時期では Smad 1,6 抗体の免疫反応が歯根膜および歯間水平線維群に沿つてみられる線 維芽細胞に認められた。

Smad 4 抗体は, 他の Smads と colocalize していた。

【考察および結論】

Smad 1, 6 抗体の免疫反応は, HERS，歯根象牙質を形成する象牙芽細胞，セメント芽細胞，骨芽細胞および 歯根膜中の線維芽細胞に観察された。特異型および抑制型 Smads がこれらの細胞に共存していたことは, BMP の作用は個々の細胞内で Smads の signal により複雑に調節されており, BMP は歯根および歯周組織形成におい て重要な役割を果たしているものと考えられた。現在，TGF- $\beta$ に関する Smads についても検索中である。 